Bryn Mawr College

Scholarship, Research, and Creative Work at Bryn Mawr College

Classical and Near Eastern Archaeology Faculty

Research and Scholarship

Classical and Near Eastern Archaeology

1966

\title{
Notes on the Development of the Greek Frieze
}

Brunilde S. Ridgway

Bryn Mawr College, bridgway@brynmawr.edu

Let us know how access to this document benefits you.

Follow this and additional works at: http://repository.brynmawr.edu/arch_pubs

Part of the Classical Archaeology and Art History Commons, and the History of Art, Architecture, and Archaeology Commons

\section{Custom Citation}

Ridgway, Brunilde S. 1966. Notes on the Development of the Greek Frieze. Hesperia 35:188-204.

This paper is posted at Scholarship, Research, and Creative Work at Bryn Mawr College. http://repository.brynmawr.edu/arch_pubs/62

For more information, please contact repository@brynmawr.edu. 


\title{
NOTES ON THE DEVELOPMENT OF THE GREEK FRIEZE
}

\author{
(Plates 59-60)
}

7 HIS paper does not purport to be an exhaustive study of the continuous Greek 1 frieze and of its many problems; it aims rather at recording some observations and suggesting some theories, in the hope of stimulating further discussion and comments. ${ }^{1}$ Certain difficult questions will be touched upon only in so far as they relate to my arguments, with full understanding of the fact that much is still to be learned which might considerably affect the interpretation of the subject. Excavations on the coast of Asia Minor and in the Western colonies are continually producing new material of considerable importance in the study of early architecture, and any comments on chronology and development may perhaps appear premature at this point. Yet it does seem worthwhile to submit a preliminary working hypothesis against which all new evidence may be tested either in support or rejection. It also seems appropriate to dedicate these notes to one who has so greatly furthered our knowledge of the Greek frieze.

It is irrelevant to my argument to speculate on the geographical origin of the continuous frieze. It suffices to acknowledge here the most widely accepted theory that the idea of the figural band came to the Greek world from the Orient; indeed great similarity (in form, decorative effect, general subject matter and occasional details) exists between Assyrian friezes and the early Greek terracotta revetments. ${ }^{2}$ More pertinent, however, is the issue concerning the nature and purpose of the frieze. Some scholars maintain that the frieze originated as a purely decorative form, while others believe that it served a practical function. "This latter " utilitarian" theory-

${ }^{1}$ The term "frieze" is here used to mean a continuous figural decoration, regardless of material, technique, or even architectural connections or location. Although terracotta revetments are manufactured as plaques, when they are placed in a continuous sequence and the subject matter is repetitive they qualify as friezes, in much the same way as the Parthenon frieze technically consists of individual slabs. The major work on Greek friezes is P. Demangel, La Frise Ionique, Paris, 1932, henceforth quoted as Demangel. Cf. also its review by H. Möbius, Gnomon, XI, 1935, pp. 652-656. The subject has been extensively treated recently by $\mathrm{H}$. Kähler in Enciclopedia dell'Arte Antica s.v. Fregio ; I have made frequent use of his comments and ideas in this paper.

Since I am working on a longer study of architectural sculpture, which will incorporate the content of this paper in expanded form, criticism and corrections will be most welcome.

${ }^{2}$ Some scholars maintain that the overwhelming influence of Egypt on Archaic Greek sculpture in general should not be overlooked, and seek a possible derivation and ancestry for the continuous Greek frieze in a country famous for its decoration of surfaces within registers. Möbius (op. cit.), for instance, advocates Egyptian influence, perhaps reaching the Greek mainland through Crete. Hittite and Babylonian connections are also often quoted in this respect (see, e.g., Demangel, pp. 45-49), but the time-gap between these works and Greek friezes, as well as geographical and historical difficulties, make these statements harder to substantiate.

${ }^{3}$ For instance, Demangel supports the utilitarian theory; Möbius and Kähler oppose it. 
that a carved stone frieze is merely the " petrified" version of an originally functional terracotta revetment for wooden beams-ultimately derives from the more general attempt to explain Greek architectural forms as a consistent and logical translation from wooden prototypes. This approach has been refuted elsewhere ${ }^{4}$ and can here be examined only with specific reference to the frieze.

Crucial to the question is the relative chronology of stone and terracotta friezes. Some of the "revetments" from Asia Minor, especially from non-Greek areas such as Sardis, Gordion, Pazarli, etc., had initially been dated far too early, ${ }^{5}$ thus suggesting a definite line of development from terracotta to stone. Finds from recent excavations have prompted some scholars to assert that the non-Greek versions of such terracotta friezes are appreciably later than the first Greek examples and should thus be considered imitations rather than forerunners. ${ }^{6}$ At the same time the chronology of some Greek terracottas has been revised, with the result that the question of priority has been opened once again. ${ }^{7}$ This difficult problem need not concern us here, since it seems at least established that some stone friezes are contemporary with, if not earlier than, the available terracotta examples, even with reference to the " high" chronology. ${ }^{8}$

${ }^{4}$ Cf., e.g., R. Carpenter, Greek Art, Philadelphia, 1962, pp. 76-77, 218-221, 222-226, especially 225-226 for specific reference to the Ionic frieze. Cf. also Möbius, loc. cit. The 1951-1960 excavations in Olbia have indeed brought to light the remains of an Ionic temple of Apollo Delphinios with wooden columns and capitals covered by terracotta revetments. However, the temple is to be assigned to the fifth century B.c., and can therefore hardly be considered a survival of earlier practices; its unusual construction probably reflects only local difficulties in securing appropriate materials. See A. N. Karasyov, Olbia, Temenos and Agora (in Russian, with English summaries), Moscow, 1964, pp. 129-130 and p. 65, fig. 31.

${ }^{5}$ A list of these early dates can be found in A. Andrén, Architectural Terracottas from EtruscoItalic Temples, Leipzig/Lund, 1940, p. LXXX note 1. See also Demangel, passim.

${ }^{6}$ E.g., R. S. Young, A.J.A., LXVI, 1962, p. 154, note 5; LXVIII, 1964, p. 284 ; also E. Akurgal, Die Kunst Anatoliens, Berlin, 1961, p. 100.

${ }^{7}$ Of interest in this respect is the frieze from a building located $c a .10 \mathrm{kms}$. west of Hacilar in southwest Turkey (cf. M. J. Mellink, A.J.A., LXVIII, 1964, p. 159). The terracotta plaques represent a galloping rider preceded by a stately griffin; their style seems Phrygian under heavy East Greek influence. They have been dated to the first half of the sixth century by Mellink and N. Thomas ("Recent Acquisitions by Birmingham City Museum," J.H.S., Archaeological Reports 1964-65, pp. 64-70, no. 4), to the third quarter of the same century, if not later, by $\AA$. Akerström (Stockholm Medelhavsmuseet Bulletin, IV, 1964, pp. 49-53). These plaques have found their way into many European and American collections. To those listed by N. Thomas, add one plaque in the Berlin Charlottenburg-Schloss Museum, Antikenabteilung, eine Übersicht, p. 6, Room 2.

For a lower chronology of Greek terracottas, see, e.g., R. C. Bronson, "Chariot Racing in Etruria," Studi in Onore di Luisa Banti, ed. R. Bianchi Bandinelli, Rome, 1965, pp. 89-106, especially p. 92 note 17, who suggests that all Larisa terracottas may date from $c a .530$ B.C. or later. It is traditionally held that the Larisa revetments are among the earliest preserved, ranging through the sixth century B.c.

${ }^{8}$ One of the earliest stone " friezes" preserved is the row of warriors whose heads are scratched on the cella wall of the second Samian Hekatompedon dated shortly after 670 B.C., H. Berve and G. Gruben, Greek Temples, Theatres and Shrines, London, 1963, p. 450, fig. 119. The excavators, however, tended to consider this graffito not an architectural frieze but a "spielerische Zutat," E. Buschor and H. Schleif, Ath. Mitt., LVIII, 1933, p. 157, fig. 8. Cf. also G. M. A. Richter, The 
It could be argued that the extant terracottas do not represent the earliest attempts in that medium. Indeed, many of their compositions appear already "tired" and illogical, as if previously significant scenes had been abbreviated to the point of incongruity. ${ }^{9}$ It seems hardly plausible, for example, that hares or deer should be chased on horseback or in chariots, by warriors in full panoply (Pl. 59,c); ${ }^{10}$ nor can a soldier mount on a racing chariot with dignified poise and sedate pace. ${ }^{11}$ But is it justifiable to assume that the "archetypal " compositions were rendered in terracotta? Some evidence may point to other media.

Many architectural plaques are not true revetments in the sense of being nailed onto wooden beams, but formed parapet simas. ${ }^{12}$ Several of these are ornamented on their upper edge by a series of triangular projections resembling the teeth of a saw. This treatment, hardly consonant with the nature of clay, definitely seems to reflect derivation from bronze prototypes and postulates the existence of a body of evidence which may now be totally and understandably lost. ${ }^{13}$ Fortunately the tradition of using metal decorations in architecture is well attested not only by Oriental practices, ${ }^{14}$

Portraits of the Greeks, London, 1965, pp. 19-20, who considers the warriors' heads an archaic example of sketching or doodling. In actual relief an early example is provided by the row of horsemen from Prinias, Crete, dated ca. 650 B.c. (below, pp. 194-195). W. B. Dinsmoor, The Architecture of Ancient Greece, London, 1950 (hereafter Dinsmoor), p. 47, calls it "the prototype of the parapet-simas moulded or carved in relief."

${ }^{9}$ This observation is made by Demangel, pp. 434-435, who attributes the incongruity to contamination of motifs and a progressive elimination or transformation of the symbolic meaning attaching to Assyrian and Oriental prototypes.

${ }^{10}$ Ch. Picard, Mon. Piot, XXXVIII, 1941, pp. 55-92, especially p. 66, believes that the apparent discrepancy can be resolved if one interprets the hunting scenes in the light of religious symbolism. It seems more probable, however, that the various animals were introduced as filling ornaments, in imitation of contemporary vase painting or perhaps even to emphasize the concept of speed, and thus have no connection with the riders (below, p. 194).

${ }^{11}$ Cf., e.g., the terracotta plaque from Palaikastro in Crete (best illustrated in the photograph B.S.A., XL, 1940, pl. 17). Similarly incongruous seems the contrast between the galloping rider and the dignified griffin of the non-Greek frieze mentioned above, note 7. N. Thomas (loc cit.) suggests that it is incorrect to describe the one as pursuing the other, and that their relation is only symbolic, the griffin suggesting royalty or divinity. Akerström (op. cit.) considers that the knight is neither hunting nor fighting but " just out for a ride."

${ }^{12}$ Dinsmoor (p. 64) notes that these terracotta parapet-simas " may justly be regarded as the prototypes of the sculptured Ionic friezes of Periclean Athens." For an unusual form of sima cf. the horseman/griffin frieze of note 7 and the reconstructions by N. Thomas, figs. 4-5 and Akerström, fig. 4. The shape seems to combine sima and geison revetment.

${ }^{13}$ On the general question of the use of bronze in Greek architecture see P. Verzone, "Il bronzo nella genesi del Tempio Greco," Studies Robinson, I, St. Louis, 1951, pp. 272-294, more specifically 282-283. To his list of surviving bronze "friezes" add a metal frieze (?) with chariot procession from Artemis Orthia, B.S.A., XXVII, 1926-27, p. 106, fig. 7. See also H. Drerup, Mitt., V, 1952,

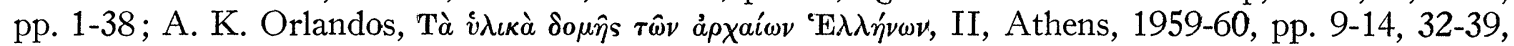
especially p. 14 note 29. The triangular projections of terracotta simas were sometimes moulded separately and fastened to the sima with metal pins; cf. e.g., Andrén, op. cit., p. LXXXII, note 5.

${ }^{14}$ Cf. e.g. H. Frankfort, The Art and Architecture of the Ancient Orient, 1954, p. 89; Demangel, Chapter III. 
but even by such Greek survivals as the fourth century B.c. frieze of the Propylon in Samothrace or the cast egg and dart moulding from the Hieron in the same sanctuary. ${ }^{15}$ It has also been suggested recently that the figures decorating the epistyles of both the Didymaion and the Doric temple at Assos might be understood as imitations of metal appliqué work, ${ }^{16}$ and a similar origin might account for the decoration of the early Sidonian sarcophagi. ${ }^{17}$ A frieze of bronze figures against a neutral architectural background may be visualized in the cast-bronze warriors and chariots processing around the neck of the Vix krater, ${ }^{18}$ a suggestion corroborated not only by their technical peculiarity of having been made separately from the rest of the vase, but also by the choice of subject-matter which seems to be a favorite of early friezes.

On the strength of present knowledge, therefore, it seems justifiable to surmise that the earliest friezes might have been executed in stone as well as terracotta and even metal (appliqué or repoussé work), without strict dependence or derivation of one type from another. Considered in this variety of forms and media, friezes definitely suggest that their nature was not exclusively, perhaps not even primarily, functional but mostly, if not entirely, decorative. As is often the case, truth lies in the middle, and therefore neither the "utilitarian" nor the "decorative" theory is entirely wrong. It is important, however, to determine the proportion in which the two elements combined to form the continuous figured band. It is my contention that the ornamental element was indeed predominant, to such an extent that even subject matter and narrative became subordinate, and that the figured frieze originated as a

${ }^{15}$ Propylon: K. Lehmann, Hesperia, XXI, 1952, p. 28; none of the bronze ornaments is actually preserved, but their nature can be inferred from the technique employed to attach the decoration to the stone. The cast egg and dart moulding was mentioned by Mrs. P. W. Lehmann in a paper presented to the 56th General Meeting of the AIA (summarized in A.J.A., LXVIII, 1964, pp. 196-197).

${ }^{16}$ See Kähler, op. cit. Perhaps a similar suggestion could also be made for the maidens standing around the columns of the Didymaion. Their applique quality derives not only from the presence of the flutes between the figures, which suggests the integrity of the column shaft, but also from the frontal pose of the maidens as contrasted with the processional quality of the reliefs on the Ephesos column drum. On the other hand one cannot deny the similarity between the maidens of the Didyma columns and the caryatids employed in Ionic structures of smaller scale. For a reconstruction of the Didyma columns see G. Gruben, Jahrb., LXXVIII, 1963, pp. 78-177, fig. 39, especially pp. 106-112, fig. 10. Contrast the dance portrayed on a circular base (column drum?) from Kyzikos, E. Akurgal, Antike Kunst, VIII, 1965, pp. 99-103.

${ }^{17}$ F. Hiller, " $\mathrm{Zu}$ den Sarkophagreliefs des späten 4. Jh. v. Ch.," Marburger Winckelmannprogramm, 1961, p. 30, comments that the decoration of the Lycian sarcophagus, with its strip of ground line extending only under the feet of the figures, has the appliqué character of terracotta revetments.

${ }^{18}$ See, e.g., the illustration in $\AA$. Akerström, "Untersuchungen über die figürlichen Terrakottafriese aus Etrurien und Latium,” Opus. Rom., I, 1954, pp. 191-231, fig. 34. Åkerström uses the frieze on the krater as representative of the vehicle (minor arts) through which certain Greek motifs might have reached Italy. On the Vix krater in general see Mon. Piot, XLVIII, 1954, pls. 9-13. For a Roman marble copy of a possible archaic bronze frieze representing a man with horses (and perhaps even an original chariot) see E. Harrison, Athenian Agora, XI, no. 127, pp. 77-79, pl. 29. 
form of representational pattern or glorified moulding. ${ }^{19}$ I use the term " moulding" in its etymological sense of " anything cast in a mould" (Webster's New Collegiate Dictionary) to emphasize the repetition of decorative patterns usually employed for mouldings, as well as their purely ornamental quality as corollary to the architecture.

If my contention is sound, a frieze, like a moulding, should be suitable for any number of positions within an architectural structure. This point is proved, indirectly, by the difficulty excavators experience in their reconstructions whenever a relief is found dissociated from its architectural context; ${ }^{20}$ it is directly proved by the attested or postulated presence of friezes as terrace parapets, on column drums, at the bottom of walls as well as at their tops, along the walls themselves, over epistyles, or at the edges of roofs as parapets and simas. ${ }^{21}$

We should moreover expect to find in early friezes all the traits required of a good decorative pattern: potential continuity, that is, the ability to cover a long and

${ }^{19}$ Technically speaking, the frieze could be termed a "figured tainia"; Kähler, op. cit., points out that the surface of early friezes originally projected beyond the face of the epistyle. Some temples exist in which the frieze area is decorated with patterns more commonly employed for traditional mouldings; see, e.g., the archaic temple of Athena in Paros, with a three-fasciaed epistyle surmounted by a frieze of three tiers of egg and dart (Dinsmoor, p. 132); or the late fourth century B.C. Ionic temple of Hemithea at Kastabos in the Karian Chersonese, whose " most remarkable feature is the frieze": a shallow cyma with carved lotus and palmettes and no dentils, J.H.S., Archaeological Reports 1964-65, pp. 57-58, fig. 26. Carpenter, op. cit., pp. 226-227, makes a similar point when he claims that the Ionic frieze origirated as a wall crown; contrast, however, Dinsmoor's opinion (above, note 12).

${ }^{20} \mathrm{Cf}$. Kähler, loc. cit. This difficulty is enhanced by the apparent lack of correlation between the composition of the frieze and the enframing architecture. Early Ionic decoration usually employs juxtaposed motifs and repetitive figures, as contrasted with the more tectonically articulated friezes of Classical Greece; see below, especially pp. 198-201.

${ }^{21}$ Terrace parapets: Xanthos, Akropolis, Fouilles de Xanthos, II, 1963, fig. 28, pl. $33: 1$.

Column drums: Ephesos, BrBr 148.

Tops and bottoms of walls: Samos, Rhoikos temple, Berve and Gruben, p. 453; Polykrates temple, ibid., p. 455: E. Buschor, Ath. Mitt., LXXII, 1957, Beil. 31-43. Myus, Temple of Dionysos, H. Weber, Ist. Mitt., XV, 1965, pp. 43-64, especially p. 49, note 11, pp. 63-64.

Along walls: Xanthos, op. cit., fig. 14, pls. 38-39.

Architraves: Didyma, Gruben, Jahrb., LXXVIII, 1963, p. 158, fig. 39. Assos, F. H. Bacon, J. T. Clarke, R. Koldewey, Investigations at Assos, Cambridge, Mass., 1902-21, pp. 145-151.

Parapets and Simas: Ephesos, Berve and Gruben, p. 459, fig. 126. Miletos (Karaköy), BrBr 101b, Kähler, op. cit. Larisa on Hermos, L. Kjellberg, Larisa am Hermos, II, Stockholm, 1940; A. Akerström, Architektonische Terrakottaplatten in Stockholm, Lund, 1951. Thasos, Ch. Picard, Mon. Piot, XXXVIII, 1941, pp. 55-92; M. Launey, Études Thasiennes, I, Paris, 1944, pp. 37-39, pl. 7.

It is generally believed that the Greeks did not decorate the structural parts of their buildings, but only those that were not essential to the construction. However, Gruben, Jahrb., LXXVIII, 1963, p. 176, has advanced the theory that a decorated epistyle in Ionia may be the rule rather than the exception, and the ultimate origin of the canonical friezes in Delphic Treasuries. To his list of decorated epistyles (Assos, Didyma, the Nereid Monument in Xanthos) one may perhaps also add as late an example as the first century B.c. Doric temple of Apollo Bresaeus in Lesbos, Dinsmoor, p. 271. 
narrow area without an obvious beginning, center, and end; clarity and intelligibility, even from a distance; repetition and uniformity, mixed with enough variation to arouse interest and dispel monotony, but not enough to break the rhythm or distract attention from the overall effect. ${ }^{22}$ These qualities are achieved through the choice of subject matter.

I have already suggested that if emphasis were placed on the decorative aspect of the frieze, its subject matter by necessity would become subordinate. There are few mythological episodes represented on archaic Ionic friezes, and even those are not primarily treated as story-telling but depicted with an over-abundance of repetitive side-figures. ${ }^{23}$ Aside from these sporadic instances, whatever narrative exists in an early frieze seems largely limited to the typical features in the life of a ruler. Banquets, reception of tribute and offerings, even hunting scenes, ${ }^{24}$ as impersonal representations of a certain standard of life, can be considered neither historical nor mythological. It is even doubtful whether a generic allusion to human activities should be read in the two subjects by far the most popular on ancient friezes, the chariot race and the galloping rider.

It has been suggested that a procession of chariots may depict burial rites, if found on a funerary monument, races or war games if on a palace or temple. ${ }^{25}$ Such meaning, though not to be entirely excluded, is nonetheless insignificant when com-

${ }^{22}$ To Demangel's remarks (pp. 462-465 and passim) that monotony and repetition are fostered by the technical process of making terracotta plaques from moulds, Picard, Mon. Piot, XXXVIII, 1941, p. 61, replies that the Thasian terracottas show enough variation to exclude the theory of purely mechanical reproduction. Both comments are valid as proof of the point I am trying to make. A similar uniform rhythm exists in the traditional Doric frieze with its alternation of triglyphs and metopes; indeed this form of decoration prompted Drerup's comment that the Doric frieze, and consequently early Doric architecture, must have originated in the Geometric period (Arch. Anz., 1964, cols. 180-219, especially cols. 206-207).

${ }^{23}$ The evidence for these subjects is fragmentary and, at best, ambiguous. Mythological episodes, especially Herakles' centauromachy, seem to appear in some of the early friezes, but in some cases the identification is doubtful, in others the date is sufficiently late to warrant "Doric" influence, and finally some fragmentary terracottas may be votive rather than architectural. At Assos the episodes involving Herakles have been represented with an abundance of repetitive side-figures, such as the fleeing Nereids, or with emphasis on the decorative cavalcade of centaurs. For a puzzling architectural fragment (frieze ?) with a narrative content (warriors defending a shrine from attacking chariotry) from Chania in Crete, and dated early seventh century в.c., see J. Boardman, The Cretan Collection in Oxford, Oxford, 1961, pp. 137-138, fig. 53; F. Matz, Forschungen auf Kreta 1942, Berlin, 1951, pl. $56: 5$.

${ }^{24}$ To quote a few examples at random:

Banquet scenes: Larisa, Kjellberg, Larisa am Hermos, II, pls. 22-23. Kebren, Terracotta plaques from a temple or palace, J.H.S., Archaeological Reports 1964-65, p. 35, fig. 3.

Reception of offerings: Xanthos, Harpy tomb, $\mathrm{BrBr}$ 146-147.

Hunting scenes: Gordion, terracotta plaque, Åkerström, Arch. Terrakottaplatten in Stockholm, p. 44 , fig. 17 .

${ }^{25}$ On chariot racing see R. C. Bronson, op. cit.; Åkerström, Opus. Rom., I, 1954, pp. 191-231. 
pared with the ornamental potential of the figures. The dashing horizontals of the galloping horses, the sinuous outline of the charioteer bending eagerly forward to second the motion, the interplay of lines and curves created by wheels, spokes and legs of horses, all contribute to form a composition eminently suitable for clear and immediate perception and of highly decorative value.

Many examples of such chariot friezes exist in terracotta, especially from Larisa (P1. 59, a). The popularity of the motif is further attested by a recent discovery at Phokaia: fragments of a frieze which, though from a different geographical area, derive from the same moulds employed for the decoration of Larisan buildings. ${ }^{26}$ In stone, the same subject matter finds widely different expression in two slabs from Kyzikos, almost lace-like in their treatment of decorative details, and a series of fragments from Myus, emphatic in their preference for smooth surfaces and plastic volumes (Pl. 59, b) ${ }^{27}$ It is significant that the same motif was adopted in antiquity for the decoration of areas other than architectural, such as the surface of many vases ${ }^{28}$ or even the embroidered border of a chiton. ${ }^{29}$

Only second in popularity is the frieze of riders, also used for a variety of decorative purposes and in a number of positions. In the numerous terracotta examples, the knights are usually accompanied by flying birds and coursing dogs, often also by game, moving at top speed in the same direction as the rider and therefore emphasizing the impression of continuous parallel movement. More unusual is the variant provided by a non-Greek frieze, ${ }^{30}$ where a galloping rider follows an almost static griffin, in a curious alternation of lively and lifeless patterns. In stone specimens, the riders tend to appear unaccompanied, almost as if the various animals of the terracotta revetments were considered as filling ornaments typical of minor arts and therefore inappropriate to the more monumental medium. Within this group falls the earliest preserved relief frieze in stone, the horsemen from Prinias (P1. 59, d) who in their

${ }^{26}$ E. Akurgal, A.J.A., LXVI, 1962, p. 379, pl. 101, figs. 24-25. Miss Nancy Bookidis of Bryn Mawr College deserves the credit for noticing that the Phokaian reliefs come from Larisan moulds.

${ }^{27}$ Kyzikos reliefs, Akurgal, Kunst Anatoliens, p. 238, fig. 207. Myus, C. Blümel, Die archaisch griechischen Skulpturen der staatlichen Museen zu Berlin, Berlin, 1963, figs. 193-211; new fragments in H. Weber, Ist. Mitt., XV, 1965, pp. 43-64. It is not the purpose of this paper to give lists of monuments with related subjects. Comprehensive discussion can be found in Demangel under the appropriate headings.

${ }^{28}$ For chariot races or defilés cf. especially Geometric vases (e.g., P. Devambez, Greek Painting, London, 1962, figs. 33-34) where decorative elements prevail over narrative. Important is the chariot race on the François vase, placed in a position of structural importance (the base of the neck) as would suit a moulding. But the Attic spirit turns the purely decorative scene into an epic episode by the addition of Homeric names. See J. D. Beazley, The Development of Attic Black Figure, Cambridge, 1951 pp. 34-35, pl. $11: 1$.

${ }^{29}$ E.g. on the sleeve of Euthydikos' kore, H. Schrader, Die archaischen Marmorbildwerke der Akropolis, Frankfurt, 1939, p. 79, fig. 44.

${ }^{30}$ Above, note 7. For other terracotta examples see e.g. Thasos (Mon. Piot, XXXVIII, 1941, pp. 55-92); Åkerström, Opus. Rom., I, 1954, pp. 191-231; Demangel, passim. 
cramped position over their monumental mounts strongly recall the gigantic horses of Protocorinthian or Protoattic vases. ${ }^{31}$ More lively, because later, is the spirited cavalcade of the frieze from Velletri. ${ }^{32}$ Rhythm is established by means of the interlocking tails of the animals, each neatly inserted under the chest of the steed next in line, but variety is introduced by making a rider fall from his horse. A different kind of variety prevails on the recently found base from the Kerameikos, where only minor details of costumes, coiffures and poses combine with the different spacing of the single figures to provide that varied repetition so essential in a decorative frieze. ${ }^{33}$

When and where did the fluctuating figured frieze finally crystallize into a definite position within an established architectural order? W. B. Dinsmoor has suggested the middle of the sixth century B.c. and the mainland of Greece, more precisely Delphi, where different styles from different geographic areas were brought into close contact by the panhellenic and cosmopolitan nature of the sanctuary. Standing next to Doric treasuries with their triglyph-and-metope friezes, Ionic buildings with low friezeless entablatures must have looked somewhat out of proportion. The continuous frieze was therefore placed above the epistyle, at first perhaps only to increase the height of the superstructure, but soon to be exploited as a field for decorative sculpture. ${ }^{34}$

In his turn, Demangel has suggested that it was in Delphi that the continuous frieze lost its processional quality and turned into a carefully planned composition with definite beginning, center and end. ${ }^{35}$ This is highly probable, especially in view of the fact that the Knidian Treasury, perhaps the earliest extant example of an Ionic structure with canonical frieze, presumably displayed a figured decoration only on its

${ }^{31}$ The horsemen frieze from Prinias has been restored above the epistyle by L. Pernier, A.J.A., XXXVIII, 1934, pp. 171-177, but it might have formed a parapet as at Ephesos; see, e.g., Dinsmoor, p. 47. The Prinias temple is dated ca. 650 в.c. on the basis of its sculpture. R. W. Hutchinson, Prehistoric Crete, 1962, pp. 343, 349, attempts to date the horsemen frieze earlier than the goddesses from the same building, which he attributes to a reconstruction $c a$. 600 B.c. For Protocorinthian vases see, e.g., W. Kraiker, Aigina, pl. 12, 191. For Protoattic vases, CVA, Deutschland II (Berlin I), pl. 33.

${ }^{32}$ E. Paribeni, Sculture Greche del V Secolo, Rome, 1953, no. 2. This Greek frieze, now in Rome, was found in Velletri, but its ultimate origin is unknown. The top border was once much larger and level with the heads of the figures; it was later cut back to its present height for some unknown reason.

${ }^{33}$ Kerameikos P 1001; excellently studied and described by F. Willemsen, Ath. Mitt., LXXVIII, 1963, pp. 105-109, no. 1. For the immediate purposes of this paper it suffices to point out the following intentional deviations from the pattern: while the second and fourth riders are bearded, the first and third riders are beardless; they also wear their mantles in a similar fashion and hold down the heads of their mounts. The third horse has a long mane, contrasting with the closely cropped hair of the other three horses; but only the first horse has two legs off the ground, and only the first rider wears his hair long in a chignon over the shoulder. The wider space around the first rider singles him out as the most important personage of the cavalcade.

${ }^{34}$ Dinsmoor, p. 139.

${ }^{35}$ Demangel, pp. 367-481, especially p. 470. 
façade, thus effectively limiting the extension of the composition through tectonic means. ${ }^{\text {s6 }}$

But besides fixed location and organization, I believe that the continuous frieze acquired another feature in Delphi, which was henceforth to characterize all mainland friezes: its epic, narrative content.

I have already mentioned that early Asia Minor friezes seem to draw from a peculiarly limited repertoire of narrative themes. But a whole tradition of mythological representations existed in the architectural sculpture of Greece, even more specifically of Magna Graecia. The telling of a story was at times hampered by the definite restrictions imposed by the articulation of the Doric order; so when a myth or an epic episode could not be narrated within the limits of a metopal field, the sculptor took the liberty of extending his story over two metopes, or perhaps even more, disregarding the intervening triglyphs. The typical instance of such procedure is the representation of the Argonauts' ship in the so-called Sikyonian metope (Fig. 1): only the prow of the vessel figures in one metope, while the stern appears

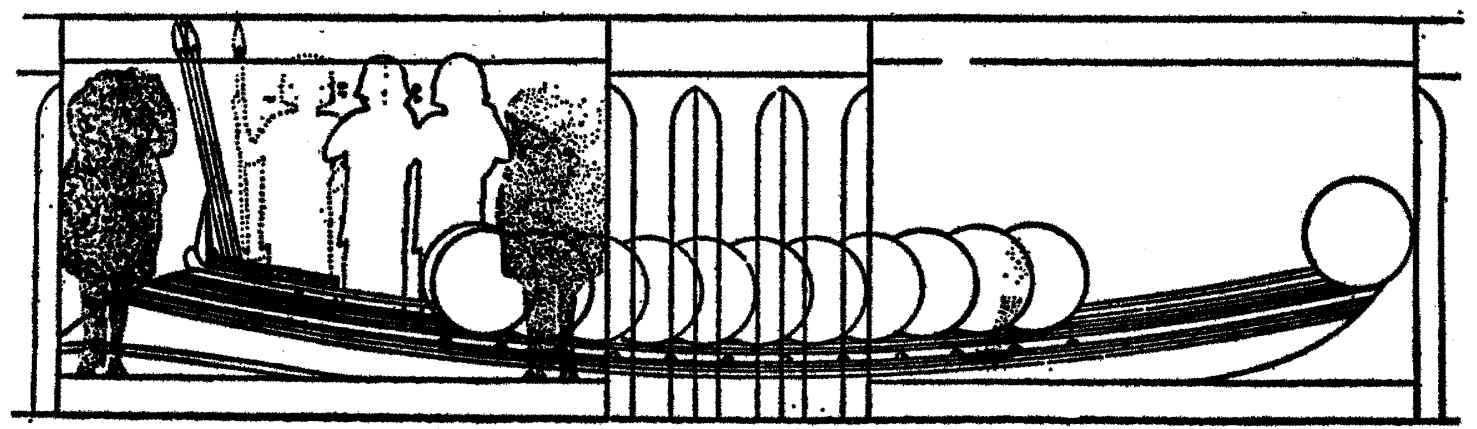

Fig. 1. Delphi, Sikyonian Treasury, Ship of the Argonauts

in the adjacent one; the main part of the boat is to be understood as hidden by the intervening triglyph, gliding behind it as it were, suggesting to the spectator that he is enjoying a distant vista through two windows. ${ }^{37}$ More frequent, though less startling, is the case of archers shooting across a triglyph to a distant opponent on another metope. This practice, already exemplified in that veritable encyclopaedia of epic and mythological themes which is the archaic treasury at Foce del Sele, ${ }^{38}$ survives

${ }^{36}$ Dinsmoor, loc. cit.

${ }^{37}$ For a reconstructed drawing P. de la Coste-Messelière, Au Musée de Delphes, Paris, 1936, pp. 114-115, 186-187, fig. 8; a good photograph, de la Coste-Messelière, Miré, Delphes, Paris, 1943, pl. 42. For comparable impressions of distant vistas cf. Lakonian cups, e.g. P. Pelagatti, Enciclopedia dell' Arte Antica, s.v. LACONICI Vasi, p. 447, fig. 522. In monumental art one has to wait until Roman times; cf., e.g., the Odyssey landscape paintings recently discussed by B. Andrae, Röm. Mitt., LXIX, 1962, pp. 106-117 Beil. 1 and P. von Blanckenhagen, Röm. Mitt., LXX, 1963, pp. 100-146, pls. 44-53, especially pp. 102-103, note 10.

${ }^{38}$ P. Zancani Montuoro and U. Zanotti Bianco, Heraion alla Foce del Sele, II, Rome, 1954, 
down to the time of the Hephaisteion and the Parthenon. In the Athenian Treasury at Delphi it occurs within the depiction of a single episode on six consecutive metopes occupying the entire west side of the building: Herakles shoots the three-bodied Geryon across a triglyph, while the remaining four metopes are filled by cattle, meekly and monotonously arranged in twos. ${ }^{39}$

It might therefore be said that the archaic Doric metopes were already exploited as a potential continuous frieze. The Ionians, on the contrary, possessed the ideal surfaces for sculptural narration but preferred to use them exclusively for ornamentation. It is logical to assume that when these two different traditions came in contact, the Doric ${ }^{40}$ masters were quick to seize the opportunity of incorporating a continuous frieze into their buildings or even to turn the Ionic " figured fascia" into a narrative vehicle.

Perhaps the most revealing example in support of this theory is the ambivalent treatment of the Siphnian Treasury frieze. It is generally believed that the north and east sides were decorated by a master differing in style and technique from the artist who carved the south and west friezes. ${ }^{41}$ The former sculptor, master B for easy reference, brought a sculptural approach to his work and conceived his scenes almost as compositions in the round, with definite margins and focal points. This is especially evident on the east side, where the frieze is treated as two separate halves to be understood also as on different levels, since the assembly of the gods is presumably taking place in Olympos, while the battle rages in a more earthly sphere. Each of these two sections centers around an axial point clearly emphasized by the change in direction within the groups of figures. In the battle scene Nestor-unheeded at the extreme right-seems at first to have been left out of the composition, despite his efforts to bridge his isolation by means of his raised arm and his shouted advice. But looking at the entire east side, one perceives that the warrior is perfectly balanced at the other end of the frieze by a figure similarly detached from his companions, Ares, whose heavy shield demands greater " elbow room" and therefore achieves that isolation that marks the god psychologically as an unpopular member of the assembly and materially as a definite frame to the composition. ${ }^{42}$ This organization within the frieze combines

pl. 19 (a centauromachy stretching over the entire east side and occupying six metopes), pl. 21 (north side) and pl. 22 (south side); for the themes of the metopes, pp. 109-110; on the influence of Stesichoros, p. 106; on the relationship of metopal composition to triglyphs, p. 88 and note 1 , p. 91. On the newly found metopes from the same building and their contribution to the evaluation of epic influence, see P. Zancani Montuoro, Atti M. Grecia, N.S., V, 1964, pp. 57-59.

${ }^{39}$ Fouilles de Delphes, IV, 4, Paris, 1957, pls. 66-67, 69 (five metopes).

${ }^{40}$ The terms Ionic and Doric are not used in a strict ethnic sense, but merely to differentiate between the makers of decorative friezes and those of narrative metopes, i.e., generally Asia Minor vs. Greece/Magna Graecia.

${ }^{41}$ de la Coste-Messelière, Au Musée, pp. 415-436; B. S. Ridgway, B.C.H., LXXXVI, 1962, pp. 24-35.

${ }^{42}$ Good illustrations in Delphes, figs. 76-77, 78-79, 80-81. 
with its epic content. Thought at first to represent a generic Homeric duel without specific parallel within the poem, a new reading of the inscriptions near the fighting warriors has revealed that the encounter takes place over the body of Sarpedon, thus depicting a definite episode of the Patrokleia from the 16th book of the Iliad. ${ }^{43}$

By the same master, the Gigantomachy on the north side, though presumably arranged around three chariots, presents less obvious foci but evident beginning and end. It is the first and last representation of the gigantomachy to be entirely successful, since the heavy fighting does not break up into "metopal" duels, but is conceived as two streams of combatants, identified as gods or giants by their very direction. Apollo and Artemis shoot distant opponents, a giant flees in terror at the approach of ferocious lions already maiming one of his companions, giants and gods face each other across fallen bodies, in a variety of planes and a density of composition which vividly reflects the melée of battle, even if it destroys the long-range clarity required of a frieze. ${ }^{44}$ It is perhaps significant that this epic masterpiece has been attributed to an Attic master on the basis of the dialect and script of the signature (now unfortunately partly lost) engraved over a giant's shield. ${ }^{45}$

If Master B was Attic, Master A, his collaborator on the south and east sides, might have been a native Siphnian or at least an "Ionian" trained in the decorative school of processional friezes. Though perhaps specific mythological episodes are represented also on his two sides of the building, the emphasis is definitely on the ornamental value of the frieze, and we return to the clear definition of applique figures in single file, neatly outlined against the spacious background, with processional parallelism in one plane. Typically enough, the subject matter involves many riders and chariots. We seem, literally and paradoxically, to lose the narrative because of the horses. But what we miss in story-telling we gain in comprehension, in the rhythm of a decoration that can be appreciated most, and almost exclusively, from a distance. ${ }^{46}$

From this moment onward the continuous frieze passes into the hands of Attic masters who firmly anchor it to an architectural frame while continuing to exploit its narrative potentialities. This definition of limits is at times imposed or made possible by the physical location of the frieze. ${ }^{47}$ In the Hephaisteion, for instance, only the porches are embellished by sculptured strips, extending from anta to anta on the west, from peristyle column to peristyle column on the east. The west Centauromachy breaks up in groups strongly reminiscent of metopal arrangements, and the correlation between sculpture and architecture is not obvious or well thought-out. The east frieze, on the contrary, is a carefully planned composition, indissolubly bound to the

${ }^{43}$ E. Mastrokostas, Ath. Mitt., LXXI, 1956, pp. 74-76.

${ }^{44}$ Delphes, figs. 82-85.

${ }^{45}$ M. Guarducci, "Lo scudo iscritto nel fregio del Tesoro dei Sifnî a Delfi," Studi in onore di Luisa Banti, Rome, 1965, pp. 167-176.

${ }^{46}$ Delphes, figs. 66-67 (west frieze), 72-73 (south frieze).

${ }^{47}$ For the plans of Doric temples with continuous Ionic friezes see Demangel, p. 319, fig. 68. 
surrounding architecture. The subject matter, similar in its component elements to the east Siphnian frieze, breaks the divine assembly into two groups, each surrounded by fighting warriors. But the battle over the passageways is relatively calm; the more intensive fighting toward the center allows for the placing of the two recumbent figures directly over the columns; the hero of the episode is glorified by his position over the central span, while the two semicircles of divine spectators gravitate directly over the antae. How strictly logical this arrangement is, almost a structural requirement, is proved by a drawing in Stuart and Revett (P1. 60, a) where the position of blocks 4 and 5 has been inverted and the seated deities therefore appear over a column, with the second fallen warrior over the northeast anta. One almost feels the compulsion of shifting position again; had we not known the correct arrangement, we would have guessed it on the negative evidence of this drawing. ${ }^{48}$

A similar strict connection between architecture and sculpture exists in the diminutive Nike Temple frieze from the Athenian Akropolis. ${ }^{49}$ Here the division between gods and men is at the same time emphasized yet made less abrupt by the limited size of the structure: the battle scenes can deploy over three sides, leaving the entire east front to the divine assembly. The intentional placing of standing draped figures over the columns has already been noticed; ${ }^{50}$ it is almost a continuation into the entablature of the Ionic fluting, or a subconscious reminiscence of Doric triglyphs. Equally important is the arrangement of the seated figures, one over each intercolumniation, and, over the central span, two seated flanking two axial standing figures. The battle scenes offer no such tectonic correlation, mainly because they stretch largely over blank walls, but an attempt has been made to place the fallen warriors of the west side directly over the columns. ${ }^{51}$ The diminutive size of the frieze requires a wide spacing of figures for the sake of clarity, but there is nothing pictorial in this surrounding "atmosphere"; the individual episodes remain purely sculptural in their fractioning, even if the flamboyant style of the late fifth century tends to bridge gaps by means of flying mantles.

What the Nike temple master accomplishes through sheer size, the Parthenon master obtains through ingenuity. His divine assembly still gathers on the east,

${ }^{48} \mathrm{~J}$. Stuart and N. Revett, The Antiquities of Athens, new ed., London, 1827, chapter I, pl. 7. For a drawing showing the frieze in relation to the architecture (though only partially), see $\mathrm{H}$. Koch, Arch. Anz., XLII, 1928, cols. 706-721, figs. 2-3. Good photographs and recent discussion, C. Morgan, Hesperia, XXXI, 1962, pp. 221-235, pls. 77-84. This theory of carefully planned and strict correlation between architecture and sculpture opens up new vistas on the collaboration between ancient sculptor and architect in the building of a temple. Unfortunately all too often the sculpture is illustrated or discussed in isolation, without reference to the enframing architecture.

${ }^{49}$ Good photographs, Ch. Picard, L'Acropole d'Athènes: L'enceinte, l'entrée, le bastion d'Athéna Niké, les propylées, Paris, 1929, pls. 37-40; see also C. Blümel, Der Fries des Tempels der Athena Nike, Berlin, 1923; Jahrb., LXV-LXVI, 1950-51, pp. 159-165 and pp. 135-158 passim.

${ }^{50}$ Ibid., p. 151.

${ }^{51}$ I owe this observation to Miss K. Ellen Roberts of Bryn Mawr College. 
amidst festive worshippers represented in sculptural if not geographical proximity; ${ }^{52}$ a unified subject, in spite of the enormous length of the building, encircles the remaining three sides of the cella.

It is significant that in order to achieve this unity, Pheidias had to revert to a processional theme reminiscent of archaic Asiatic prototypes and including a considerable number of " decorative" horses and chariots. In our tendency to stress the originality of the Panathenaic frieze we tend to overlook the strongly traditional elements in its composition; yet Pheidias' genius lies primarily in the fact that he could disguise an old-fashioned scheme under the appearance of a real event which periodically took place in contemporary Athens: a procession in honor of Athena similar in spirit to a Roman triumph, requiring the participation of colonies and allies and thus resulting in an open display of imperial power highly suited for the decoration of the Parthenon, the most monumental of all victory trophies.

"Archaic" is not only the scheme, but also the juxtaposition of apparently disconnected elements, in this case riders, chariots, sacrificial animals, musicians, men and women carrying different objects. Yet this variety is required by the very nature of the procession and is thus turned into inherent unity by the underlying theme. Finally, individual features of the Parthenon frieze are at times as incongruous as some of the early terracotta revetments from Asia Minor: galloping horses are fronted by calmly standing pedestrians, chariots race headlong toward impassive marshals. Yet the lively positions of the animals are justified by aesthetic and decorative reasons ${ }^{53}$ while the static poses of the men are imposed by the need to slow the action down and make evident that a solemn procession, and not a rowdy cavalcade, is involved. Pheidias is still strongly bound by the tectonic conventions of the Periklean age. He therefore adopts the processional pattern, but tries to alter it by introducing figures facing in the opposite direction and beckoning to distant companions. In order to retain the "Doric" framing of a frieze, he breaks the motion at the beginning and the end of each side, so that each of the four friezes can be seen as a unit complete in itself as well as a part of a more encompassing whole. He even takes the liberty of inverting the actual order of the Panathenaic procession, making the riders and cavalry leave last, rather than first, so that the conclusion of the frieze, over the

${ }^{52}$ It has been suggested that the gods should be understood as being on Olympos, while the human beings are thought of as on the Akropolis; P. Fehl supports this contention with a study of the ground line: J. Warb., XXIV, 1961, pp. 1-44. For a brief but good discussion of the frieze, P. Corbett, The Sculpture of the Parthenon, 1959, pp. 15-23; for illustrations, R. Lullies and M. Hirmer, Greek Sculpture, London, 1957, pls. 148-161.

${ }^{53}$ The outline of a galloping or rearing horse is much more enjoyable than that of the same animal standing still. For the same aesthetic reasons, and for added variety, some of the human figures are made to rest their feet on rocks seemingly sprouting from nowhere at convenient locations. I agree in general with Fehl in his attempt to interpret some Parthenonian rocks as part of a specific landscape, but I also believe that many such rocks are only expedients and stage props to ensure liveliness and variation of poses. 
columns of the east porch, can have the solemn majesty appropriate to the main façade. The pleated skirts of the marching maidens echo the quiet rhythm of the fluted shafts below them.

What makes the Parthenon frieze such a masterpiece of architectural sculpture is indeed its connection with the surrounding architecture. It is also its decorative character emphasized by the uniform direction, its low relief with the consequent clarity of outlines for individual figures, perhaps even its very monotony within each group with only minor variations for added attraction, ${ }^{54}$ in sum, all the features typical of a " glorified pattern" type of frieze. ${ }^{55}$

What happens when the sculptural interest overrides all other considerations is best exemplified by the Bassae frieze. ${ }^{56}$ The very position of the sculptured band, within the interior of the cella over columns of peculiar shape and with two different capitals, tends to disassociate the frieze from the architecture. This divorce is also emphasized by the choice of two different subjects, with no tectonic division possible between the two because of the uneven number of slabs involved. Rather than a "glorified moulding" supplementing the architectural features of the building, the Bassae frieze is an element of the temple in its own right, demanding individual attention and consideration. Its relief is high, its composition crowded. The human figures tend to occupy all the available space, and therefore appear too stout and massive, with wide faces and squat bodies. The background has ceased to be an integral part of the composition and the groups have to be studied at close quarters to be fully understood. Too much is going on at the same time $\left(\mathrm{Pl} .60, \mathrm{c}^{57}\right)$; the frieze is a congeries not only of motifs borrowed from other friezes, pediments, metopes and even grave reliefs, but also of different styles. ${ }^{58}$ A master who enjoys flamboyant

${ }^{54}$ The typical example is the slab with four youths carrying water jars (north frieze, slab VI, Lullies and Hirmer, op. cit., pl. 158). The last boy is bending over to lift his vessel and therefore follows a pattern of his own, but the remaining three figures are remarkable for their similarity of outlines, which suggests that the same cartoon was employed for them all. This is especially evident along the contour of the right sides with the protruding knees all at the same level. The variation occurs within the figures themselves, which are grouped by twos through similar traits. For instance, the first and second carry the water jar with both hands, while the third uses only his right; the first and third have their chest covered by the mantle, while the second shows his torso half bare; finally the faces of the second and third youths are represented in three-quarter view, while the first is represented in complete profile. But none of them makes an exactly identical gesture or wears his mantle in quite the same way.

${ }^{55}$ It is perhaps significant that Pausanias overlooked the Panathenaic frieze in his description of the Parthenon. To him, a Greek of Roman times, an architectural frieze was mainly a form of "figured moulding."

${ }^{56}$ For the problem of the arrangement see W. B. Dinsmoor, A.J.A., LX, 1956, pp. 401-452; for illustrations and description, H. Kenner, Der Fries des Tempels von Bassae, Wien, 1946.

${ }^{57}$ The typical instance is the slab Br. Mus. 527, Kenner pl. 8, in which a centaur, jumping over the body of a dead comrade, kicks the shield of an attacking Lapith with its hind legs, while biting the neck of another who plants a dagger in its chest.

${ }^{58}$ Standard comparisons involve the Nike Temple frieze, the Hephaisteion frieze, the Parthenon 
drapery swirling around the figures has worked side by side with a master whose hallmark seems to be stretched skirts, garments that hamper the wearer with a series of ugly horizontal folds from leg to leg. A sculptor with a vigorous modelling technique is followed by one who prefers pictorial devices, such as a chariot seemingly emerging from a corner or a centaur foreshortened like a Christ by Mantegna. There is no underlying unity of artistic conception, and subject matter fails to prove an adequate cohesive agent. Interesting as the Bassae frieze may be in itself, as an architectural element it is a total failure. In the direction of sculptural narrative it represents the end of the line.

Inevitably the frieze goes back to its ornamental, non-narrative character. And it is significant that this process should begin in Asia Minor, where the decorative frieze had originated. The Nereid Monument in Xanthos, ${ }^{59}$ though built by Greeks or by Greek-trained artisans, returns to the archaic practice of placing friezes in several different positions, including the epistyle. Though one of these friezes is typically "mainland" in character (the so-called pseudo-Amazonomachy), the others narrate the exploits of an oriental ruler, revive the traditional hunting scenes with diminutive figures clearly spaced over an empty background, emphasize repetition and processional rhythm in the row of hunters bringing food to a banquet or in the dance of the warriors slanting backwards like a collapsing card castle. ${ }^{60}$

Even the Mausoleion, that most Greek of non-Greek buildings decorated by the most famous Greek masters of the mid-fourth century, reverts to the decorative chariot frieze of sixth-century terracottas. Of its other friezes, the best preserved is a "sculptural" amazonomachy (P1. 60, c), ${ }^{61}$ but even here the new tendencies (or rather a return to the old ways) can be detected. The figures are widely spaced so as to be clearly visible against the background as outlines, or even as a system of lines slanting in different directions with a moulding-like regularity which obscures the traditional breaking up of the subject into individual duels. Significantly, the heads of the fighters do not reach the upper edge of the slabs, and this empty space contributes to the impression of "atmosphere" surrounding the figures.

metopes, the metopes of the Argive Heraion, the central group of the Parthenon West pediment, the Albani relief $(\mathrm{BrBr} 437)$ and the Dexileos stele.

On style see especially R. Carpenter, M.A.A.R., XVIII, 1941, pp. 28-29; E. Harrison, A.J.A., LXV, 1961, p. 190.

${ }^{59} \mathrm{BrBr} 214-218$; Mon.Inst., X, pls. 11-18.

${ }^{60}$ Akurgal, Kunst Anatoliens, p. 143, fig. 95.

I omit here a discussion of the Heroon at Gjölbaschi-Trysa (F. Eichler, Die Reliefs des Heroon von Gjölbaschi-Trysa, Wien, 1950) in spite of its many epic and mythological themes, because it appears to be strongly under the influence of contemporary painting, and is not architectural in the strict sense of the word. One may note, however, that even at Gjölbaschi there are several instances of repeated outlines especially in the scenes of siege.

${ }^{61}$ R. Lullies and M. Hirmer, op. cit., pls. 201-204. BrBr 96-100. Charioteer, E. Buschor, Maussollos und Alexander, Munich, 1950, fig. 30. 
This treatment of space is still fully sculptural and architectural. It becomes pictorial in the frieze of the Lysikrates monument, ${ }^{62}$ still tectonically articulated through the symmetric balancing of groups and the placing of important personages over the intercolumniations. But the whole composition is so widely spaced and interspersed with stage-props, such as the large kraters over the columns or the few scattered elements of landscape, that a cast of the frieze, divorced from its architectural context, conveys the impression of a representation on a Megarian bowl. That this minor-art quality is not dependent on size alone is proved by the miniature frieze of hunting scenes on the socle of the Mourning Women sarcophagus in Istanbul (P1. 60, d).$^{63}$ The relief is so low and uniform, the density of the composition so high, the background so neutral, that the spirited figures in their flying mantles usually pass unobserved and the narrative band is automatically taken for an architectural moulding. More noticeable, but equally decorative in its processional character, is the frieze crowning the sarcophagus and acting as the traditional parapet of early Ionic temples, once again a stately succession of chariots and horses.

From this moment onward, the middle of the fourth century down to $c a .180$ B.c., the frieze retains a purely ornamental character. It is either a sequence of nearly identical figures ${ }^{64}$ or a regular alternation of cult implements, garlands, boukrania, weapons. ${ }^{65}$ It is inconspicuous but it serves well its purpose of enhancing sottovoce the enframing architecture. It is a disciplined but effective manifestation of a major art in a subordinate position.

This orderly state of affairs is violently disrupted by the one period closest in spirit to the turbulent end of the fifth century B.c., the time of the Pergamene baroque. The Gigantomachy on the Pergamon altar ${ }^{66}$ explodes as the most dramatic re-elaboration of motifs and forms typical of Periklean Athens, with a sculptural emphasis comparable only to the Bassae frieze. Once again the actors tend to occupy all avail-

${ }^{62}$ For a photograph of a cast of the frieze see F. Hiller, Marburger Winckelmann-programm, 1961, pp. 29-30, fig. 1, pl. 7.

${ }^{63} \mathrm{~F}$. Hiller, " $\mathrm{Zu}$ den Sockelfriesen des Klagefrauensarkophagus in Istanbul," Marburger Winckelmann-programm 1960, pp. 1-12, p1. 1. For the sacrophagus as a whole, O. Hamdy-Bey, Th. Reinach, Une nécropole royale à Sidon, Paris, 1892, pls. 6-11.

${ }^{64}$ E. g., relief of dancing women from Samothrace (K. Lehmann, Hesperia, XX, 1951, pp. 16-18, pls. 8-10) ; frieze of Erotes from the north slope of the Athenian Akropolis (O. Broneer, Hesperia, IV, 1935, pp. 143-145, pls. 34-35). The chronology of both these reliefs, traditionally placed within the fourth century B.C., has recently been challenged in favor of a mid-second century в.c. date; C. H. Mitchell, A.J.A., LXVIII, 1964, pp. 50-51, note 28.

${ }^{65}$ At Samothrace the bronze cult implement frieze (Hesperia, XXI, 1952, p. 28) and a frieze with garlands and boukrania (Hesperia, XX, 1951, pl. 7) ; friezes of weapons, garlands and boukrania at Pergamon (Precinct of Athena, Stoa and Propylon; E. Rohde, Pergamon, Burgberg und Altar, Berlin, 1964, p. 15, fig. 5, p. 17, fig. 7, p. 18, fig. 8), at Miletos (Bouleuterion: A. W. Lawrence, Greek Architecture, 1957, pls. 144-145) and elsewhere.

${ }^{66}$ Altertümer von Pergamon, III, 2, H. Winnefeld, Die Friese des grossen Altars, Berlin, 1910; E. Rohde, op. cit. 
able space; the bodies writhe together in impossible contortions; the drapery swirls around the figures with an animation of its own. The feathery texture of wings contrasts with the scaly skin of snakes or the rough fur of lions and dogs. The giants are no longer the humanized hoplites of the Siphnian frieze; there are bull-giants, giants with lion heads, with wings made of leaves, with fin-like transitions to serpentine legs. To fight against such unnatural opponents the gods themselves need extraordinary helpers and unusual weapons : satyrs, winged horses, lions, dogs, constellations, thunderbolts. All the animated attributes of the various divinities, such as Athena's snake or Zeus's eagle, formerly used in art only as a means of quick idientification of their patrons, have now turned into fighting participants, thus overcrowding the action. In order to appreciate such details the frieze, rather than comprehended as a whole from a distance, should be read like a poem at close quarters, both metaphorically and literally. Indeed, scholarship was amply used to populate the vast area dictated by the architectural scale, and the names of the figures appear written above them, on the crowning moulding, thus forcing the "reader" to stand at a short distance. The background disappears from sight and the figures, worked almost fully in the round, commit the ultimate sin of overstepping their boundaries, spilling over the steps and invading the world of the living. ${ }^{67}$ Insubordinate to its architectural setting and technically ambiguous as relief, the Pergamon sculpture can hardly be called a frieze. The end of the line has been reached once more. The frieze can now only return to its inconspicuous monotony or be transformed into a pictorial and historical record under the Romans. ${ }^{68}$

Bryn Mawr College

Bryn Mawr, Pa.

Brunilde S. Ridgway

${ }^{67}$ Rohde, op. cit., p. 86, fig. 46. It is interesting to compare the giant crawling onto the steps of the altar with the fifth century Nike from the Nike balustrade ( $R$. Carpenter, The Sculpture of the Nike Temple Parapet, Cambridge, Mass., 1929, p. 10, p1. 1) which unobtrusively mounts the last step in unison with the visitor to the bastion, almost like an image reflected in a mirror.

${ }^{68}$ I omit discussion of the friezes of the temple of Apollo Smintheus at Chrysa in the Troad, the Temple of Dionysos at Teos and the Temple of Apollo at Alabanda because they are imperfectly known and almost totally unpublished. The Amazonomachy of the Temple of Artemis at Magnesia, with its high relief and relatively small proportions under the large dentils, exemplifies the return to monotony and moulding-like effects; the frieze of the Temple of Hekate at Lagina already reflects Roman influence (M. Bieber, The Sculpture of the Hellenistic Age, 2nd ed., New York, 1961, figs. 702-707). 
PLATE 59
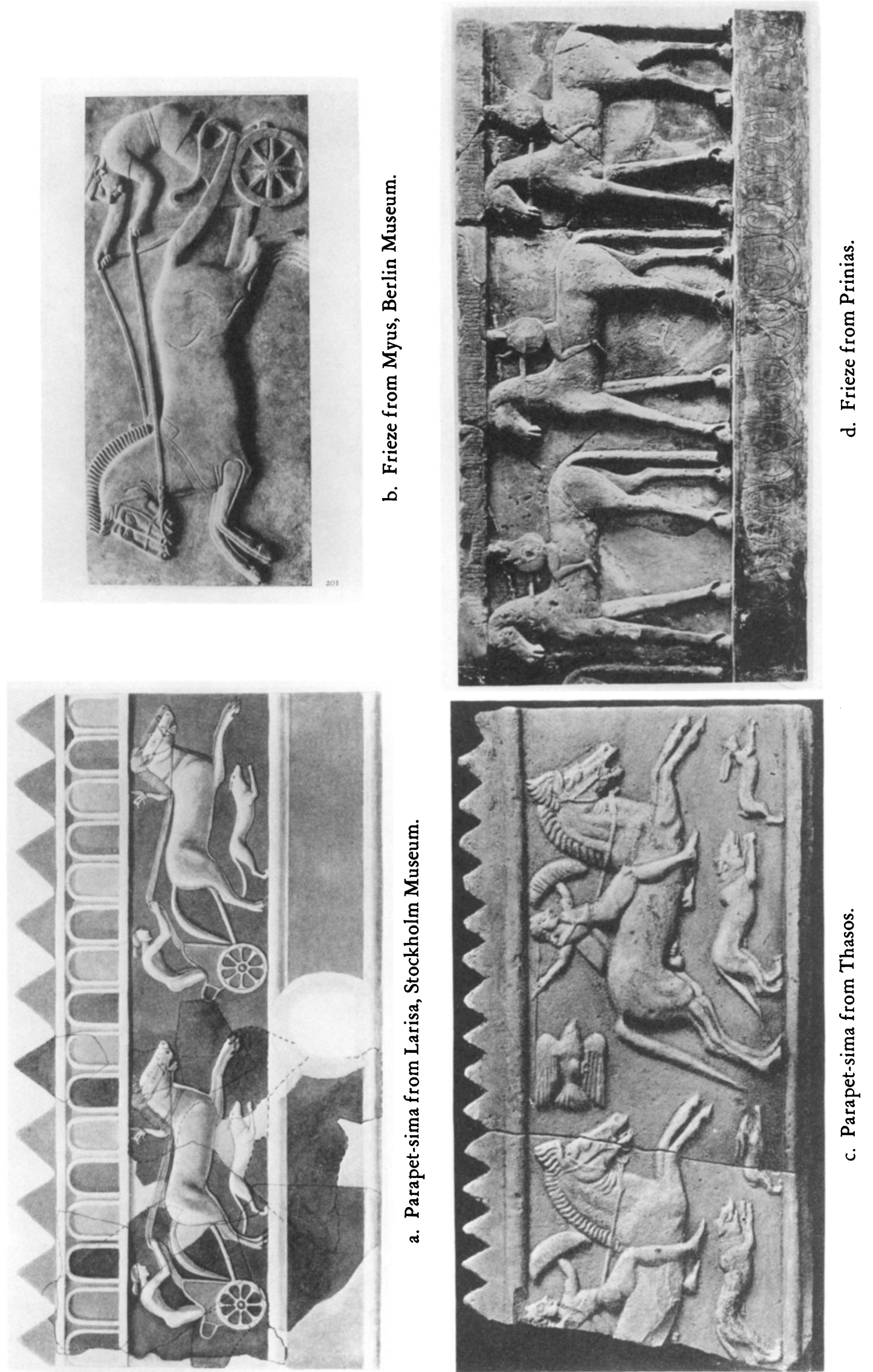

垈 


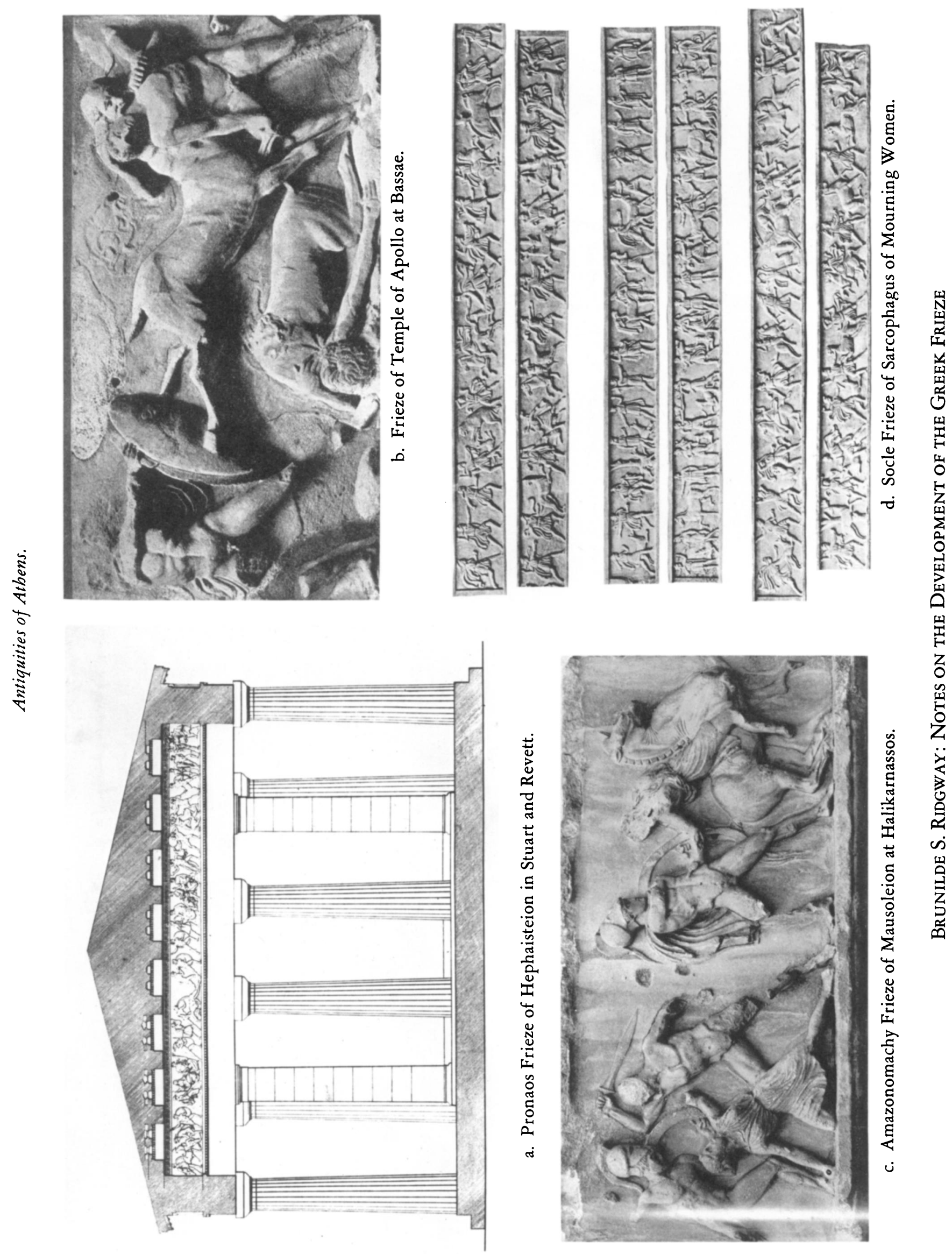

